6

\title{
Confocal Microscopy of Plant Cells
}

\author{
Carol L. Wymer, Alison F. Beven, Kurt Boudonck, and \\ Clive W. Lloyd
}

\section{Introduction}

The increasing availability of confocal microscopy has begun a revolution in plant biology in which microscopy has again become a powerful tool for understanding structure and function. Examples of applications include: threedimensional (3D) reconstruction of the interphase microtubule array in large vacuolated epidermal cells (1); measuring cytoplasmic free calcium changes in whole maize coleoptile segments in response to phototropic and gravitropic stimuli (2); and studying symplastic phloem connections in intact Arabidopsis roots (3). The major reason for this revolution is the ability to collect clear images in three dimensions due to the lack of image degradation caused by out-of-focus light. Plant cells can attain very large sizes (hundreds of micrometers, in some cases) and are very thick. Thus the ability of the confocal microscope to obtain optical sections of tissues from which 3D reconstructions can be made surpasses the limitations of conventional "wide-field" microscopic techniques where microtome sectioning is often required and cells must be viewed as flat, two-dimensional objects. Furthermore, the reduction in out-offocus flare increases depth discrimination.

The purpose of this chapter is twofold: to discuss some of the unique features of plant cells that should be borne in mind during sample preparation for confocal microscopy and to provide some example protocols as start-off points for new applications. The discussion is directed mainly toward fluorescence imaging because it is the major application of our laboratories and virtually all biological confocal microscopy is fluorescence. These protocols are based on those used in conventional epifluorescence microscopy with the key point being that in preparing tissue for confocal microscopy it is essential to retain the tissue's 3D structure. 


\subsection{Unique Features of Plant Cells}

\subsubsection{The Cell Wall}

The cell wall is a composite material composed primarily of polysaccharides and proteins. Cellulose microfibrils, distributed in highly ordered patterns, are the main component of the cell wall. These are interlinked by hemicelluloses, pectins, and proteins. The result is an extracellular matrix that can be $100-200 \mu \mathrm{m}$ thick in primary cell walls and can withstand $0.3 \mathrm{MPa}$ of pressure. It is estimated that the pore size of this matrix would seriously restrict molecules larger than $5 \mathrm{~nm}(4)$, and so provides a serious barrier for antibody or nucleic acid probes. This penetration problem is generally dealt with in one of two ways. The first is to section the material, thus bypassing the need for the probe to penetrate the cell wall. The second is to partially degrade the cell wall with specific enzymes for cellulose, hemicellulose, or pectin. Enzymatic digestion can be very effective, but it is important to keep the treatment time short to minimize the loss of cell morphology and cell separation. In addition, these enzyme preparations are often contaminated with proteases. The goal of enzymatic digestion is to loosen the cell wall enough to allow probes to penetrate, without sacrificing structure.

In addition to polysaccharide and protein, cell walls may also contain waxy substances such as cutin (this is especially true for epidermal cells) or lignin. Although such compounds provide the cell with an excellent first line of defense against pathogen attack and water loss, they also make penetration of fixatives and probes difficult. In the case of tissues and whole organ segments, vacuum infiltration can help to get the fixative throughout tissue more completely and so improve fixation. Extraction of the tissue with an nonionic detergent such as $0.1 \%$ Tween- 20 or $0.5 \%$ Triton X-100 for $10-15$ min can also improve penetration.

One final consideration with respect to the cell wall is its autofluorescence. The occurrence of autofluorescence in primary cell walls is highly variable, but autofluorescence of secondary cell walls (as in xylem thickenings) is quite common. This fluorescence is relatively broadband, and hence difficult to remove with filtration. Although the source of the fluorescence is not certain, it is believed to be caused by phenolic compounds.

\subsubsection{Vacuole}

The vacuole has a number of functions including maintaining cell shape, providing the force necessary for cell expansion, and acting as a repository for select molecules. The size of the vacuole is greatly dependent upon the developmental stage of the cell. Rapidly dividing cells contain a number of small 
vacuoles so that the ratio of the vacuole to the cytoplasm volume is relatively low. Once cells stop dividing, the small vacuoles coalesce into a single, large central vacuole. Most mature, terminally differentiated cells have a very high vacuole to cytoplasm volume ratio. The presence of the vacuole, then, has several implications for the microscopist. For the microscopist interested in preserving structure in fixed specimens, it may be necessary to include an osmoticum in the fixative to maintain osmotic balance during the fixation process or to embed the tissue to prevent it becoming flattened. For the microscopist trying to study living cells on the microscope, efforts must to be made to prevent the cell from drying which can cause changes in turgor and thus changes in cell behavior. Methods for maintaining living cells on the microscope stage have been discussed previously (5) and so are discussed only briefly below.

A particular consideration when studying living cells is the potential for the sequestration of dyes by the vacuole; this is especially important when using dyes for quantification (6). A number of workers have noted this when using calcium-measuring dyes such as fura-2 (7). To combat sequestration, dyes can be bound to high molecular weight dextrans to prevent their transport across the tonoplast. Alternately, ratiometric dyes can be utilized. Ratiometric dyes experience a shift in either excitation or emission properties upon binding an ion. In this way, the ratio of bound to unbound dye can be measured making accumulation of dye by the vacuole much less important. Regardless of the method of quantification used, it is critical that proper control measurements are made.

\subsubsection{Chloroplasts}

Although it is easy to remember the role of chlorophyll role in absorbing light for photosynthesis (peaks at 430, 454, 595, and $643 \mathrm{~nm}$ for chlorophyll $b$ ), it is often forgotten that chlorophyll fluoresces in the red. This fluorescence should be borne in mind when choosing an appropriate fluorochrome for fluorescence applications, particularly since because the excitation and emission peaks of chlorophyll are similar to the rhodamine-type dyes (excitation at 541-570 nm; emission at 570-595 nm). Partly for this reason, fluorochromes such as fluorescein isothiocyanate (FITC), which are excited in the blue (around $488 \mathrm{~nm}$ ) and emit in the green (around $520 \mathrm{~nm}$ ), are popular for plant applications. Chloroplasts still fluoresce when excited with blue light, but the fluorescence is red and can be distinguished from the green light emitted by the fluorochrome. In some cases, conflicts between fluorochromes and chlorophyll can be avoided by using dark-grown (etiolated) tissue or tissue lacking chloroplasts such as roots or the white sectors of variegated tissue. For situations that 
require the use of red-emitting fluorochromes in tissues containing chloroplasts, it is sometimes possible to use secondary filters such as a $575 \mathrm{~nm}$ long pass filter to remove chlorophyll fluorescence but retain the rhodamine fluorescence.

\subsection{Data Acquisition and Presentation}

As previously mentioned, the real advantage of confocal microscopy, as opposed to standard epifluorescence, is the increased resolution of cellular components due to the removal of out-of-focus light. In this way, fine detail can be resolved, even in a thick plant cell. The result is an optical section with a very narrow depth of field. This means that to image the whole of an organelle or network, numerous optical sections are required. Once such a series of images has been gathered, the images can be viewed individually or, by means of some calculations, collectively as projections. Using computer software programs, one can flip "up" and "down" through the series of sections manually or through animation. This gives the effect of focusing through the structure as if it was still on the microscope stage. Although this provides the most detail, it is not possible to view the structure as a whole (Fig. 1A-C). To view the structure as a whole, projections can be calculated. For a projected image, each pixel in the image is calculated as the sum or the maximum of the pixel values encountered along a line of sight through the data stack. This could be compared to having pictures on several overhead transparencies (optical sections) and overlaying all of them (Fig. 1D-F). A projection provides information about the structure as a whole, but results in a flattened representation of the structure. To obtain a more 3D view of the structure, projections can be calculated at incremental angles to produce a rotation. In this way the image appears to have been spun about a chosen axis (Fig. 1D,F). These two methods of presentation provide different types of information and the method used obviously depends on individual requirements. For instance, to sample the cortical microtubules beneath the convex outer wall of an epidermal cell three to five optical sections taken at $0.5-$ or $1-\mu \mathrm{m}$ intervals can be gathered and projected to provide a full (but flattened) view of this microtubule array (Fig. 1E) (8). However, to look at the microtubules as they move out of this plane and turn around the side walls, it is necessary to gather many more optical sections and then make rotations (Fig. 1D,F) (8). In addition, a pair of projections calculated at a suitable angle of separation (approximately $6^{\circ}$ ) can be viewed as a stereo-pair. Stereo-pairs are a typical way of presenting 3D information for publication, but this is not as effective as animating the structure on a viewing screen. Authors are beginning to take advantage of Internet capabilities by including Internet sites where readers can view animated data. It is anticipated that this will be an increasingly popular way for authors to display 3D images. 


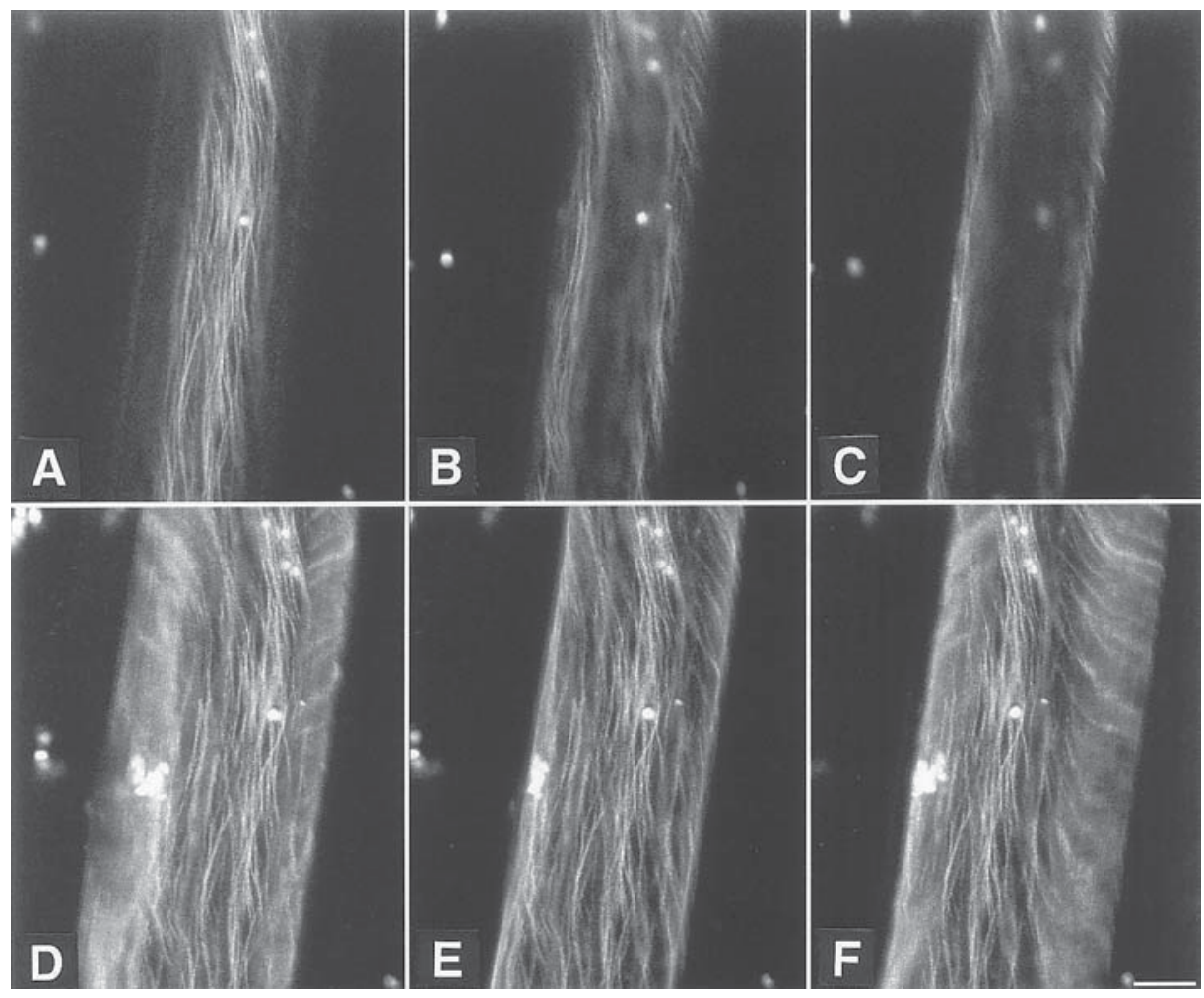

Fig. 1. Images collected with the confocal microscope can be displayed as individual images or as projections. All of the images are of a pea (Pisum sativum) epidermal cell and are part of the same data set. (A-C) Three successive optical sections taken at 1.4- $\mu \mathrm{m}$ intervals. (D) Rotation to show the cortical microtubule array under the lefthand wall of the cell. (E) A simple projection of the cell, with no rotation, to show the microtubules under the outer epidermal wall. (F) Rotation of the cell to show the microtubules under the right-hand wall. Data courtesy of Ming Yuan. Bar $=20 \mu \mathrm{m}$.

\section{Materials}

Unless otherwise stated, reagents can be obtained from Sigma (St. Louis, MO, USA).

1. Fixatives: The choice of fixatives varies widely, but they almost always contain formaldehyde as the chemical crosslinker. Formaldehyde is usually used at $4 \%$ $(\mathrm{w} / \mathrm{v})$, but it is often easier to prepare an $8 \%(\mathrm{w} / \mathrm{v})$ solution and mix it with $2 \times$ buffers. For $8 \%$ formaldehyde, weigh $0.8 \mathrm{~g}$ of paraformaldehyde into a small vial or beaker containing a small stir-bar. Paraformaldehyde should be weighed out in a fume hood. Add $10 \mathrm{~mL}$ of water and cover loosely with a lid or foil. Place the container in a beaker of water and heat to $65^{\circ} \mathrm{C}$ in a fume hood. After about 
$10-15 \mathrm{~min}$ at $65^{\circ} \mathrm{C}$, add one or two drops of $1 \mathrm{~N} \mathrm{NaOH}$. The solution should clear instantly.

a. Fixative 1: 4\% (v/v) Formaldehyde freshly prepared from paraformaldehyde

$0.1 \%$ (v/v) Glutaraldehyde

$0.25 M$ Mannitol

$50 \mathrm{~m} M$ Sodium phosphate

b. Fixative 2: $4 \%(\mathrm{v} / \mathrm{v})$ Formaldehyde freshly prepared from paraformaldehyde

$0.1 \%$ (v/v) Glutaraldehyde (preferably EM grade)

$2.75 \%(\mathrm{w} / \mathrm{v})$ Sucrose

$0.1 \%(\mathrm{v} / \mathrm{v})$ Nonidet P-40 (NP-40) in PEM 50:5:5

c. Fixative 3: 4\% (v/v) Formaldehyde

$0.1 \%$ (v/v) Glutaraldehyde (preferably EM-grade)

$50 \mathrm{~m} M$ PIPES (pH 6.9)

$1 \mathrm{mM} \mathrm{MgSO} 4$

$5 \mathrm{~m} M$ EGTA

$1 \%(\mathrm{v} / \mathrm{v})$ Glycerol

d. Fixative 4: Freshly prepared 4\% (v/v) formaldehyde in PEM 50:5:5

$0.2 \%(\mathrm{v} / \mathrm{v}) \mathrm{NP}-40$

e. Fixative 5: Freshly prepared 4\% (v/v) formaldehyde in PEM 50:5:5

$0.1 \%(\mathrm{v} / \mathrm{v})$ Glutaraldehyde

$10 \%(\mathrm{v} / \mathrm{v}) \mathrm{DMSO}$

$0.1 \%(\mathrm{v} / \mathrm{v})$ Tween-20

2. Enzymatic solutions: (see Note 1)

a. Enzyme solution 1: 0.5\% (w/v) Cellulase RC (Seishin Pharmaceuticals, Tokyo) $0.05 \%$ (w/v) Pectolyase Y-23 (Seishin Pharmaceuticals, Tokyo)

$0.5 \%(\mathrm{v} / \mathrm{v})$ Triton X-100

$0.25 M$ Mannitol

$1 \mu \mathrm{g} / \mathrm{mL}$ Protease inhibitors (such as chymostatin, and/or pepstatin) in PEM 50:1:1 buffer

b. Enzyme solution 2: 0.5\% (w/v) Cellulase R-10 (Yakult Pharmaceuticals, Tokyo)

$0.05 \%$ (w/v) Pectolyase Y-23 (Seishin Pharmaceuticals, Tokyo)

$0.1 \%(\mathrm{v} / \mathrm{v})$ Triton X-100 in PEM 50:5:5

c. Enzyme solution 3: 0.1\% (w/v) Cellulase RC (Seishin Pharmaceuticals, Tokyo)

$0.01 \%(w / v)$ Pectolyase Y-23 (Seishin Pharmaceuticals, Tokyo) in PEM 50:1:1

d. Enzyme solution 4: 0.05\% (w/v) Cellulase RS (Yakult Pharmaceuticals, Tokyo) $0.025 \%$ (w/v) Pectolyase Y-23 (Seishin Pharmaceuticals, Tokyo) $1 \%(\mathrm{w} / \mathrm{v})$ Driselase (Sigma) in PEM 50:5:5

(Note: Driselase comes from the manufacturer attached to starch grains. Prepare a stock solution at $2 \%(\mathrm{w} / \mathrm{v})$ and centrifuge it to remove the starch. Aliquots of this stock can be stored for many months at $-20^{\circ} \mathrm{C}$.)

3. Poly-L-lysine: To attach cells to slides, poly-L-lysine with a molecular weight of $>250,000$ can be used. It is prepared at $1 \mathrm{mg} / \mathrm{ml}$ in water and stored at $-20^{\circ} \mathrm{C}$. Once thawed, aliquots can be kept at $4^{\circ} \mathrm{C}$ for up to 2 weeks. Microscope slides 
should not be used directly from the manufacturer; instead they should be washed in detergent, rinsed with copious amounts of distilled water, and dried in an oven. Apply the poly-L-lysine with a cotton swab to the warm slides.

4. $\gamma$-Aminopropyl triethoxysilane (APTES): APTES (Sigma) is a bonding agent that sticks tissue down very firmly and seems to give a lower background for antibody and in situ hybridization procedures. The microscope slides are first washed in detergent and placed in a freshly prepared $2 \%(\mathrm{v} / \mathrm{v})$ solution of APTES in acetone for $10 \mathrm{~s}$ (longer incubations can result in increased background). The slides are then briefly treated in acetone and allowed to air dry. Slides prepared in this way should be used within 1 month. Just before use, the slides are placed in $2.5 \%(\mathrm{v} / \mathrm{v})$ glutaraldehyde (reagent grade) in phosphate-buffered saline (PBS) $(\mathrm{pH}$ 7.4) for at least $30 \mathrm{~min}$. Finally, the slides are rinsed in distilled water and air dried.

5. Subbing slides:

a. Wash slides in $95 \%$ ethanol and dry.

b. Dip in subbing solution.

Subbing solution: Heat $500 \mathrm{~mL}$ of water and add $2 \mathrm{~g}$ of gelatin. After gelatin dissolves, add $0.2 \mathrm{~g}$ of chrom alum (chromic potassium sulphate) while stirring. Let mixture cool, then add azide to $0.02 \%(w / v)$. Filter solution and store in refrigerator. Filter each time before use.

c. Dry slides at $60^{\circ} \mathrm{C}$.

6. Blocking solution: $3 \%(\mathrm{w} / \mathrm{v})$ bovine serum albumin (BSA), $0.2 \%(\mathrm{v} / \mathrm{v}) \mathrm{NP}-40$, in PEM 50:5:5.

7. Phosphate buffered saline: PBS can be prepared according to many different recipes based on the buffer's intended use. The following recipes are for PBS at two different pHs. PBS should be stored at $4^{\circ} \mathrm{C}$, although it can be stored at room temperature if azide is added.

PBS, pH 7.4: $8 \mathrm{~m} M \mathrm{Na}_{2} \mathrm{HPO}_{4}, 1.47 \mathrm{~m} M \mathrm{KH}_{2} \mathrm{PO}_{4}, 137 \mathrm{~m} M \mathrm{NaCl}, 2.68 \mathrm{~m} M$ $\mathrm{KCl}$, adjust $\mathrm{pH}$ to 7.4 .

PBS, pH 8.0: $4 \mathrm{mM} \mathrm{Na} 2 \mathrm{HPO}_{4}, 2 \mathrm{~m} M \mathrm{KH}_{2} \mathrm{PO}_{4}, 140 \mathrm{~m} M \mathrm{NaCl}, 3 \mathrm{~m} M \mathrm{KCl}$, adjust $\mathrm{pH}$ to 8.0 .

8. Tris-buffered saline (TBS): $25 \mathrm{~m} M$ Tris- $\mathrm{HCl}$ (pH 7.4), $140 \mathrm{~m} M \mathrm{NaCl}, 3 \mathrm{~m} M \mathrm{KCl}$.

9. Physiological buffer (PB): $100 \mathrm{~m} M$ potassium acetate, $20 \mathrm{mM} \mathrm{KCl}, 20 \mathrm{~m} M$ HEPES, pH 7.4 with KOH, $1 \mathrm{~m} M \mathrm{MgCl}_{2}, 1 \mathrm{~m} M$ ATP (disodium salt), $1 \%$ (v/v) thiodiglycol, $2 \mu \mathrm{g} / \mathrm{mL}$ aprotinin, $0.5 \mathrm{~m} M$ phenylmethylsulfonyl fluoride.

10. PEM buffers: All of the following protocols utilize a buffer composed of PIPES (pH 6.9), EGTA, and $\mathrm{MgSO}_{4}$ which is referred to as "PEM." Because each of the buffers has been developed by different individuals for different purposes, the buffer components are used in different proportions. The buffers will be referred to as "PEM 50:1:1" and "PEM 50:5:5" based on the $\mathrm{m} M$ concentration of their components. PEM buffers should be stored at $4^{\circ} \mathrm{C}$.

11. Saline sodium citrate (SSC): This buffer is used at several different concentrations in the following protocols. It is often useful to prepare a $20 \times$ stock and prepare the dilutions as needed.

$1 \times$ SSC: $150 \mathrm{~m} M \mathrm{NaCl}, 15 \mathrm{~m} M$ sodium citrate. 
12. Transcription mix: $500 \mu M$ CTP (sodium salt; Pharmacia), $500 \mu M$ GTP (sodium salt; Pharmacia), $250 \mu M$ BrUTP (sodium salt; Sigma), $125 \mu M \mathrm{MgCl}_{2}, 100 \mathrm{U} / \mathrm{mL}$ RNA Guard (Pharmacia), in physiological buffer.

13. Antibodies: Commercially available antibodies can generally be used at dilutions of $1: 100$ to $1: 400$, although it is best to check the manufacturer's recommendations. To prevent nonspecific binding, antibodies are usually diluted in $3 \%(\mathrm{w} / \mathrm{v})$ BSA. In cases where antibody penetration is a problem, better results can be obtained by using an $\mathrm{F}\left(\mathrm{ab}^{\prime}\right)_{2}$ fragment instead of the whole IgG. Most antibody incubations are not carried out at $37^{\circ} \mathrm{C}$ as is common for animal applications. Instead, incubations are carried out at room temperature, or $4^{\circ} \mathrm{C}$ in the case of overnight incubations. To prevent the antibodies from evaporating, the incubations are carried out in humid chambers: boxes containing wet paper towel. Finally, it is advisable to keep the slides out of the light during secondary antibody incubation to minimize fading of the fluorochrome.

14. Probe mixture for in situ hybridization:

$\sim 200 \mathrm{ng} / \mu \mathrm{L}$ Digoxigenin or biotin-labeled RNA probe

$\sim 1000 \mathrm{ng} / \mu \mathrm{L}$ Unlabeled RNA transcribed from a plasmid containing an unrelated insert

$50 \%(\mathrm{v} / \mathrm{v})$ Deionized formamide (reagent grade; Fisons)

$10 \%$ (w/v) Dextran sulfate (sodium salt; Sigma)

$300 \mathrm{~m} M \mathrm{NaCl}$

$10 \mathrm{~m} M$ PIPES (pH 8.0)

$1 \mathrm{~m} M$ EDTA

15. Fluorescent mounting media: There are a number of commercially available mounting media including Citifluor (Agar Scientific, UK) and Vectashield (Vector Laboratories, Peterborough, UK). Alternatively, a recipe for mounting medium is given below. Glycerol-based media that contain an antifading agent such as $p$-phenylenediamine- $\mathrm{HCl}$ are most frequently used. Best results are obtained by leaving the slides overnight to allow the anti-fading agent time to penetrate. In addition, a chromatin binding dye such as DAPI (4',6-diamidino-2phenylindole) or Hoechst 33258 (both at $1 \mu \mathrm{g} / \mathrm{mL}$ ) can be added to the medium immediately before use. Store the mounting medium at $4^{\circ} \mathrm{C}$ and add $1 \mathrm{mg} / \mathrm{mL}$ of $p$-phenylenediamine dihydrochloride immediately before use.

Mounting medium: 0.1M Tris- $\mathrm{HCl}$ (pH 9.0), 50\% (v/v) glycerol.

\section{Methods}

The following protocols have been selected because they represent a wide range of plant material (suspension cultured cells to whole roots) and because they illustrate several types of procedures (indirect immunofluorescence and in situ hybridization). They are intended as start-off points for similar applications. Additional methods for staining a variety of plant cells are given in ref. 9. 


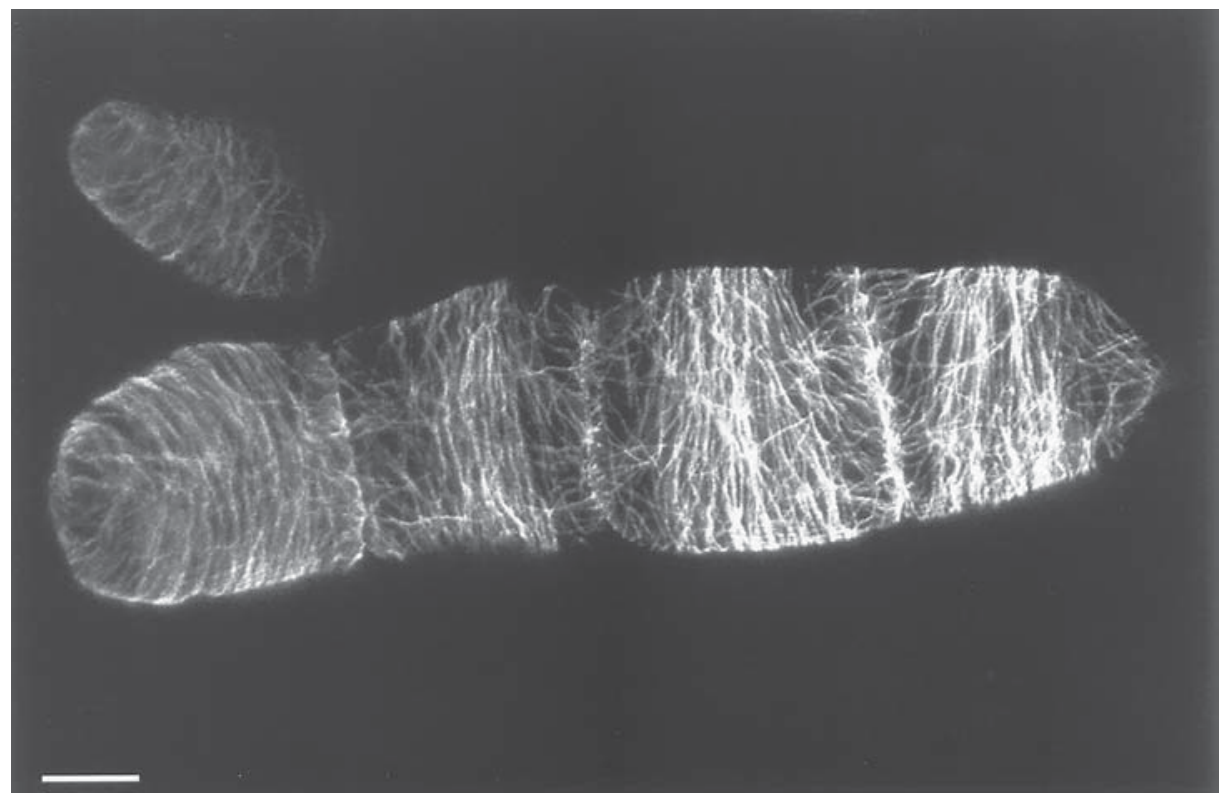

Fig. 2. Immunolocalization of cortical microtubules in the tobacco (Nicotiana tabacum) suspension culture line BY-2. The cells were taken from a 5-day-old culture which was rapidly dividing and the microtubules were labeled with YOL 1/34 (SeraLab, Crawley Down, UK). Projection of nine optical sections taken at $0.5-\mu \mathrm{m}$ intervals. $\mathrm{Bar}=20 \mu \mathrm{m}$.

\subsection{Protocol 1: Suspension Cultured Cells}

This protocol describes the immunolocalization of microtubules in the tobacco (Nicotiana tabacum) suspension culture line BY-2 (Bright Yellow-2) (Fig. 2). The BY-2 cell line has been used extensively for studying the microtubule cytoskeleton (10). The following protocol has been slightly modified from ref. 11. The same protocol has also been used for examining microtubules in carrot suspension cultures.

1. Transfer a sample of cells to a test tube.

2. Gently pellet by centrifuging at $100 \mathrm{rpm}$ for $10-15 \mathrm{~min}$.

3. Remove excess medium and add at least $2 \times$ the cell volume of Fixative 1.

4. Fix cells for $1 \mathrm{~h}$.

5. Pellet cells as before and remove the fixative.

6. Gently rinse the cells $3 \times$ by resuspending in PBS (pH 7.4) and then pelleting. At this point cells can be stored in PBS for several weeks without loss of antigenicity. 
7. Place a couple of drops onto poly-L-lysine-coated slides and allow the cells to settle for $10-15 \mathrm{~min}$.

8. Wick away the unbound cells with a piece of paper towel and extract the cells for 4-10 min using Enzyme Solution 1 to allow antibodies to penetrate.

9. Rinse for $10 \mathrm{~min}$ in PBS (pH 7.4) by dipping the slides into a beaker of PBS. When necessary, any of the following steps can be carried out overnight at $4^{\circ} \mathrm{C}$.

10. Wick away excess PBS and block nonspecific antibody labeling by treating with 3\% (w/v) BSA in PEM 50:1:1 for 15 min.

11. Treat with an anti-tubulin antibody (such as YOL 1/34 from Sera-Lab, Crawley Down, UK or anti- $\beta$-tubulin from Amersham) diluted in 3\% (w/v) BSA for at least $45 \mathrm{~min}$ at room temperature in a humid chamber.

12. Rinse in fresh PBS for $15 \mathrm{~min}$.

13. Wick away excess PBS and treat with an appropriate secondary antibody diluted in $3 \%(\mathrm{w} / \mathrm{v}) \mathrm{BSA}$ for at least $45 \mathrm{~min}$. at room temperature.

14. Rinse in fresh PBS for $15 \mathrm{~min}$.

15. Remove excess PBS and add fluorescent mounting medium containing an antifade agent.

\subsection{Protocol 2: Epidermal Peels}

Epidermal cells have long been studied by plant physiologists because of their exposed nature and because of their unique features. For example, special cell divisions within the epidermis give rise to guard cells, trichomes, and root hairs. To aid experimentation, especially microscopy, it was discovered that the epidermis of some organs of some species could be peeled away from the organ and the epidermal cells would still be viable. Many studies of guard cell behavior have been carried out this way, e.g., ref. 12. Generally, peels consist of more than the epidermis; they also contain two or three layers of cortical cells. It is critical to examine the peels under the microscope before using them because cell viability after peeling is highly variable. The following protocol is for the immunolocalization of microtubules in epidermal cells of pea (Pisum sativum) epicotyls (Fig. 3). There is great difficulty in penetrating the cell walls of these epidermal cells because of their waxy cuticle, so a brief treatment with ethanol has been added. This protocol has also been used successfully for thin, paradermal slices obtained by hand-sectioning pea stems.

1. With a flexible, double-edged razor blade, cut the stem at the base of the region of interest. This provides a large piece of stem above the region of interest to hold onto. Lightly score the stem at the top of the area of interest with the razor blade. This will provide an end for the peel, otherwise the whole segment will be peeled. Grasp the epidermis at the cut end with a pair of fine forceps and peel the epidermis away from the rest of the stem.

2. Place the peels (epidermal side up) on the sticky side of adhesive tape (a hydrophobic type such as Cellux) that has been secured to a microscope slide with double-sided tape (Fig. 3). The adhesive tape is used because the double-sided tape does not adhere 

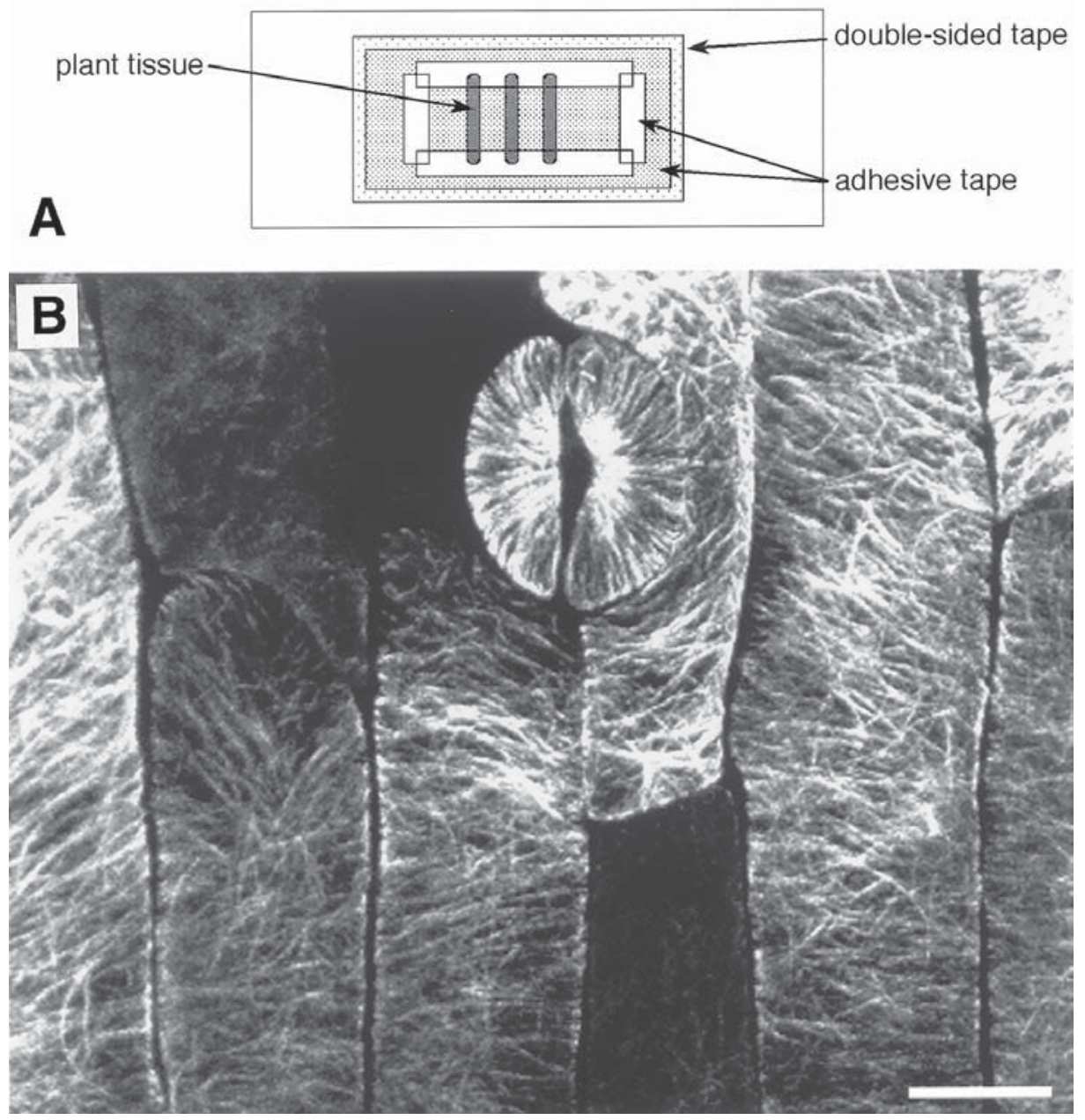

Fig. 3. Immunolocalization of microtubules in pea (Pisum sativum) epidermal cells. (A) Configuration of the tape used to secure the pieces of tissue. Double-sided tape is placed on the microscope slide and a piece of waterproof adhesive tape is placed on top of this with the sticky side up. The tissue is placed on the adhesive tape and secured with the same type of tape, placed sticky side down. (B) Cortical microtubules in the epidermal cells. The image is a projections of 11 optical sections taken at $0.5-\mu \mathrm{m}$ intervals. $\mathrm{Bar}=10 \mu \mathrm{m}$.

well once it is wet. Place a small piece of adhesive tape, sticky side down, over one end of the peels to be sure that they stay affixed to the slides during processing. By adding additional pieces of tape around the sections, a hydrophobic ring is formed. 
3. Cover with buffer ( $50 \mathrm{~m} M$ potassium glutamate, $0.5 \mathrm{~m} M$ magnesium chloride, and $2.75 \%$ sucrose) while preparing all of the slides.

4. Treat with $95 \%$ ethanol for $20 \mathrm{~s}$.

5. Remove the ethanol and rinse briefly with buffer.

6. Cover the peels with a large drop of Fixative 2 and fix for at least $2 \mathrm{~h}$. During this and subsequent incubations, the slides should be placed in a humid box to prevent drying and to contain the aldehyde fumes.

7. Remove the fixative and rinse by dipping the slide in a beaker of PBS ( $\mathrm{pH} 7.4$ ) for $15 \mathrm{~min}$.

8. Extract for $10 \mathrm{~min}$ in Enzyme Solution 2.

Note: The duration of the extraction and the choice of detergent is highly dependent on the thickness of the cell wall and the cuticle.

9. Rinse as before in PBS for 15 min.

10. Incubate in anti-tubulin antibody [diluted in $3 \%(\mathrm{w} / \mathrm{v}) \mathrm{BSA}$ ] overnight at $4{ }^{\circ} \mathrm{C}$. Inclusion of detergent $[0.1 \%(\mathrm{v} / \mathrm{v}) \mathrm{NP}-40]$ can be used to increase antibody penetration.

11. Rinse in PBS for $30 \mathrm{~min}$.

12. Incubate in secondary antibody (diluted as for the primary antibody) for $6 \mathrm{~h}$.

13. Rinse in PBS for $30 \mathrm{~min}$.

14. Mount in fluorescent mounting medium containing an antifade agent.

\subsection{Protocol 3: Immunofluorescence of Tissue Sections}

This protocol describes immunolocalization in plant root sections cut on a vibratome. The vibratome uses a razor blade that vibrates to and fro across the tissue as the section is cut. Typical sections from pea (Pisum sativum) roots are $30-40 \mu \mathrm{m}$ thick and contain about two layers of cells. Vibratome sectioning is most successful using dense, rigid tissue such as root tips. Much less success is achieved using highly vacuolated tissue such as leaf tissue. Also, species with very small roots, e.g., wheat (Triticum), are more difficult to section than those of species with larger roots, e.g., pea (Pisum sativum) and maize (Zea mays). The use of sections, rather than other preparative methods such as squashes, has the advantage that both good 3D structure and positional information are preserved (Fig. 4).

1. Excise the apical 3-4 mm of a freshly germinated pea root and fix in $4 \%(\mathrm{v} / \mathrm{v})$ formaldehyde in PEM 50:5:5 for $1 \mathrm{~h}$ at room temperature.

2. Wash the roots in PEM 50:5:5 for $15 \mathrm{~min}$.

3. Cut $30-40 \mu \mathrm{m}$ sections on the vibratome.

4. Allow the sections to air dry onto APTES-coated multiwell slides.

5. Digest the cell wall by incubating in $2 \%(\mathrm{w} / \mathrm{v})$ Cellulase R-10 (Yakult Pharmaceutical, Tokyo) in TBS for $1 \mathrm{~h}$.

6. Wash the slides $2 \times$ for 10 min each in TBS.

7. Apply the primary antibody in $3 \%(\mathrm{w} / \mathrm{v}) \mathrm{BSA}$ (prepared in TBS) and incubate for approximately $45 \mathrm{~min}$ at room temperature. 

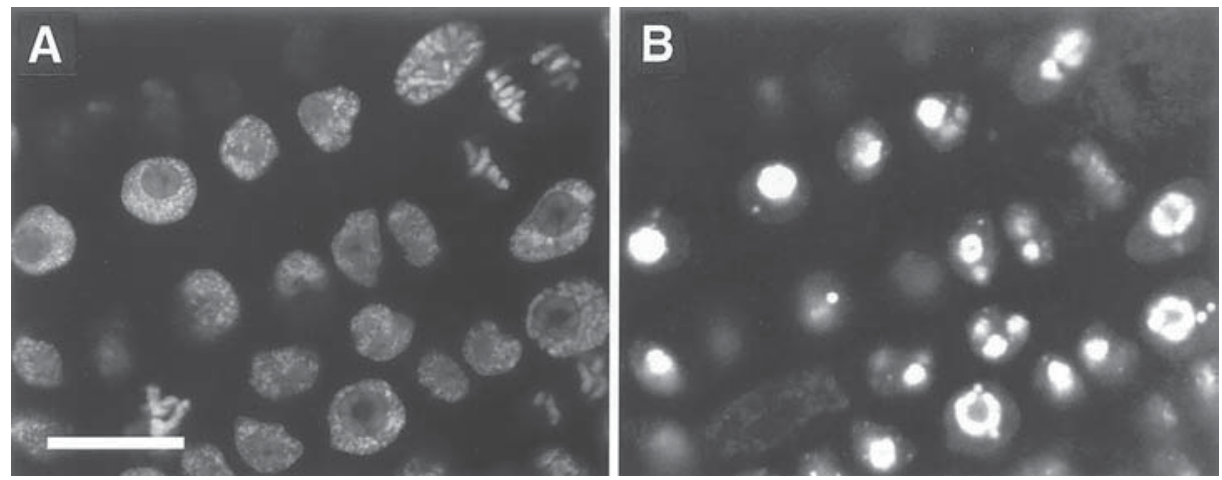

Fig. 4. Distribution of the nuclear protein fibrillarin in tissue sections of pea (Pisum sativum) roots. (A) This image is a single confocal section showing DAPI-labelling of the chromatin. (B) A single confocal section of the same area as in (A) showing the distribution of fibrillarin detected with anti-fibrillarin antibody (72B9; the generous gift from E. Tam and B. Ochs of Scripps Research Institute, La Jolla, CA, USA). The contrast has been adjusted in (B) to be able to see the fainter labeling in mitotic cells which has resulted in over-saturation of the interphase cells. Bar $=10 \mu \mathrm{m}$. (Figure reprinted with permission from ref. 13.)

8. Wash slides $3 \times$ for $10 \mathrm{~min}$ each in TBS.

9. Incubate in secondary antibody diluted in $3 \%(\mathrm{w} / \mathrm{v}) \mathrm{BSA}$ (prepared in TBS) for approximately $45 \mathrm{~min}$ at room temperature.

10. Wash again in TBS: $3 \times$ each for $10 \mathrm{~min}$.

11. Treat sections with DAPI $(1 \mu \mathrm{g} / \mathrm{mL})$ for $5 \mathrm{~min}$ to stain chromatin.

12. Wash briefly in TBS and mount in Vectashield.

\subsection{Protocol 4: In Vitro Transcription in Tissue Sections}

The following protocol describes the localization of transcription sites in root tip sections. Because this procedure uses unfixed material, several factors must be carefully controlled to ensure optimal detection of transcription. The quality of the starting material is crucial. Only healthy, recently germinated, well growing roots should be used. The sectioning procedure, from the excision of the root tip and cutting of sections on a vibratome, to the permeabilization step (which allows substrates to pass into the cells) should be as quick as possible, ideally no longer than $5 \mathrm{~min}$. The solutions used are designed to match, as nearly as possible, the ionic conditions inside the cell to ensure the RNA polymerases can continue to transcribe during the procedure. The sections are incubated in a transcription mix that contains a modified nucleotide triphosphate (BrUTP) and under these conditions, any engaged polymerases will continue to transcribe and incorporate the modified nucleotide. This modified base 


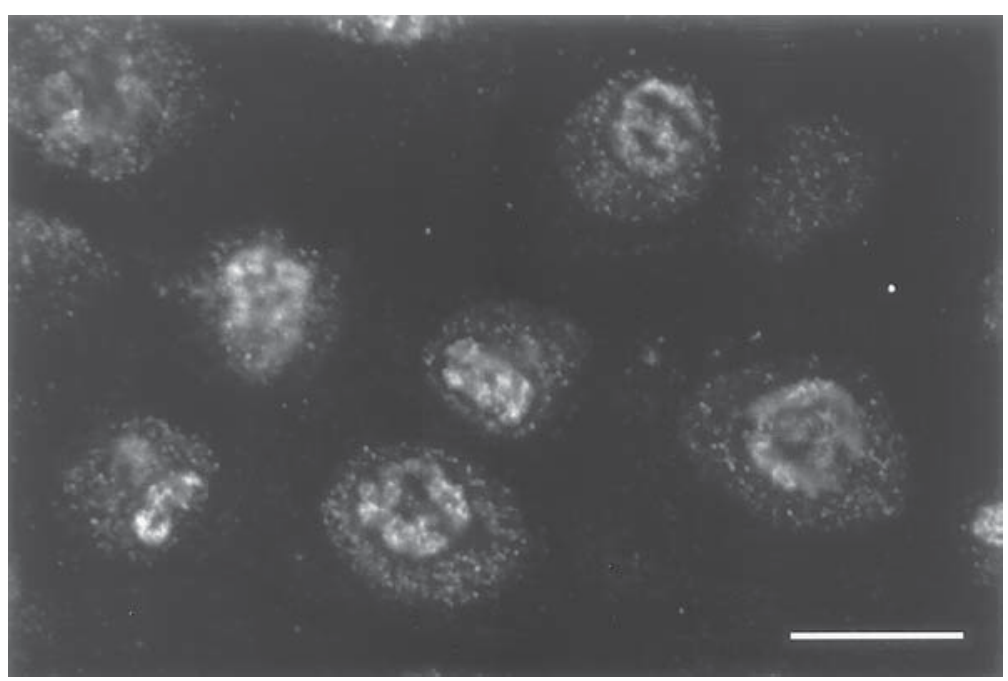

Fig. 5. In vitro transcription in pea (Pisum sativum) root sections. A single optical section of pea root tissue showing BrUTP incorporation by RNA polymerases I and II. The labeling comprises many closely packed small foci, which in the nucleolus form a more continuous region. $\mathrm{Bar}=10 \mu \mathrm{m}$.

can subsequently be detected by a specific antibody. The following protocol was modified for plant systems from an original method by Hozak et al. (14). It has been used with good success in pea (Pisum sativum) (15) (Fig. 5), maize (Zea mays), rye (Secale), and wheat (Triticum).

1. Excise the apical $3-4 \mathrm{~mm}$ of a freshly germinated root tip and mount it on a vibratome. Cut sections $(40-50 \mu \mathrm{m})$ in physiological buffer (PB) containing $1 M$ hexylene glycol (2-methyl-2,4-pentanediol) and transfer to tissue handling device (16).

2. Incubate in $0.05 \%(\mathrm{v} / \mathrm{v})$ Triton $\mathrm{X}-100$ in PB for $1 \mathrm{~min}$.

Note: Shorter Triton treatments give better nuclear transcription, whereas longer treatments result in predominantly nucleolar transcription.

3. Wash in PB alone-three washes over $\sim 30 \mathrm{~s}$.

4. Incubate in Transcription Mix for 2-10 min depending on the degree of incorporation required.

5. Wash again in PB alone-three washes over $\sim 30 \mathrm{~s}$.

6. Fix in 4\% (v/v) formaldehyde prepared in PEM 50:5:5 for $1 \mathrm{~h}$.

7. Wash in TBS for 10 min followed by distilled $\mathrm{H}_{2} \mathrm{O}$ for $10 \mathrm{~min}$.

8. Remove from tissue handling device and allow to air dry onto APTES-coated multiwell slides.

9. Treat sections with 2\% (w/v) Cellulase R-10 (Yakult Pharmaceutical, Tokyo) in TBS for $1 \mathrm{~h}$.

10. Wash in TBS-three changes over $15 \mathrm{~min}$. 
11. Incubate for $1 \mathrm{~h}$ with primary antibody: mouse anti-BrDU (Boehringer Mannheim) diluted 1:20 with 3\% (w/v) BSA in TBS.

12. Wash thoroughly with TBS.

13. Incubate for $1 \mathrm{~h}$ with fluorescent secondary antibody: Cy3-conjugated donkey anti-mouse (Jackson ImmunoResearch Laboratories, West Grove, PA, USA) diluted 1:100 with 3\% (w/v) BSA in PEM 50:5:5.

14. Mount in Vectashield or other antifade mountant.

\subsection{Protocol 5: Tissue In Situ Hybridization with RNA-Digoxygenin or RNA-Biotin Probes}

The following protocol describes in situ localization in root tissue sections using RNA probes labeled with either digoxygenin or biotin [modified from a method by Highett et al. (17)]. This procedure can also be used with a minor modification to localize DNA probes, but in this case the probes need to be heat denatured prior to the in situ hybridization. In adapting this method to different species, consideration of the enzymatic digestion step could be important for enabling optimal penetration of the probes. In all cases, we recommend using a probe size of no more than 100 base pairs, again, to ensure good tissue penetration. The stringency of the procedure can be controlled by varying both the temperature and the salt concentration of the washing step. Higher temperature, combined with a low-concentration salt solution, gives the highest stringency. This procedure has been used with success on pea (Pisum sativum) (18) (Fig. 6), maize (Zea mays), rye (Secale), wheat (Triticum), and onion (Allium cepa).

1. Fix roots in $4 \%(\mathrm{v} / \mathrm{v})$ formaldehyde and $0.1 \%(\mathrm{v} / \mathrm{v})$ glutaraldehyde [or $4 \%(\mathrm{v} / \mathrm{v})$ formaldehyde alone] in PEM 50:5:5 for $1 \mathrm{~h}$ at room temperature. Addition of glutaraldehyde yields better tissue preservation, but can make penetration of the probe more difficult.

2. Wash in PEM 50:5:5.

3. Cut $30-40 \mu \mathrm{m}$ sections on the vibratome.

4. Allow sections to dry onto APTES-coated multiwell slides.

5. Treat sections with a freshly prepared solution of $\mathrm{NaBH}_{4}(1 \mathrm{mg} / \mathrm{mL})$ in $\mathrm{PBS}(\mathrm{pH}$ 8.0) for $15 \mathrm{~min}$. Aspirate off and repeat three more times. This step is necessary only when the fixative contains glutaraldehyde. PBS is used in this step instead of TBS because $\mathrm{NaBH}_{4}$ reacts with Tris.

6. Incubate in $2 \%(\mathrm{w} / \mathrm{v})$ Cellulase R-10 (Yakult Pharmaceuticals, Tokyo) in TBS for $1 \mathrm{~h}$ at room temperature.

7. Wash in TBS for $5 \mathrm{~min}$ and then in $0.1 \times \mathrm{SSC}$ for $5 \mathrm{~min}$.

8. Incubate in $0.1 \times \mathrm{SSC}$ at $98^{\circ} \mathrm{C}$ for $5 \mathrm{~min}$. and then transfer immediately into icecold $0.1 \times$ SSC. This step is necessary only when detecting double-stranded DNA.

9. Remove surface liquid from the slide wells and add $10 \mu \mathrm{L}$ of ice-cold Probe Mixture. Place slides in a humid chamber at $37^{\circ} \mathrm{C}$ overnight. 

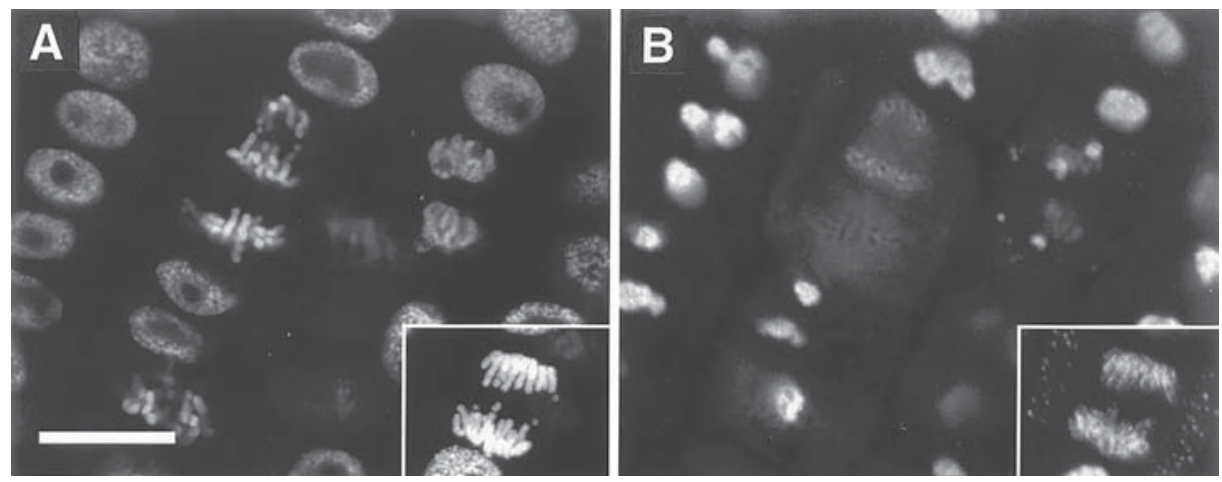

Fig. 6. Determination of the distribution of the external transcribed spacer (ETS) probe in pea (Pisum sativum) root sections using in situ hybridization. (A) This image is a single confocal section showing DAPI-labelling of the chromatin. (B) A single confocal section of the same area as in (A) showing the distribution of nascent and newly completed pre-rRNA transcripts detected with an ETS probe (18). The contrast has been adjusted in (B) to make it possible to use the fainter labeling in mitotic cells which has resulted in over-saturation of the interphase cells. The inserts show a projection of a whole cell that is further down in the same 3D data set. Bar $=10 \mu \mathrm{m}$. (Figure reprinted with permission from ref. 13.)

10. Wash in $0.1 \times \mathrm{SSC}$ at $50^{\circ} \mathrm{C}$ for $1.5 \mathrm{~h}$ with three changes.

11. Antibody detection-Remove excess wash buffer and apply antibodies diluted in $3 \%(w / v)$ BSA prepared in TBS. Use dilutions recommended by manufacturer and incubate at room temperature for approximately $45 \mathrm{~min}$ each. Wash thoroughly with TBS between antibody incubations.

Antibody detection schemes:

For digoxigenin-labeled probes:

$1^{\circ}$ Mouse anti-digoxin (anti-digoxin crossreacts with digoxigenin; Sigma)

$2^{\circ}$ Cy3-conjugated anti-mouse (Jackson ImmunoResearch Labs., West Grove, PA, USA)

For biotin-labeled probes:

Extravidin Cy3-conjugate (Sigma)

12. Counterstain with DAPI $(1 \mu \mathrm{g} / \mu \mathrm{L})$ for $3 \mathrm{~min}$.

13. Rinse in TBS and mount in Vectashield (Vector Laboratories, Peterborough, UK) or other antifade mountant.

\subsection{Protocol 6: Microtubules and Chromosomes in Root Tip Squashes}

In this procedure microtubules are immunolocalized in root tip cells. The great advantages of these cells are: (1) they have a high proportion of wellcharacterized mitotic figures; and (2) these small, nonvacuolated cells can be 

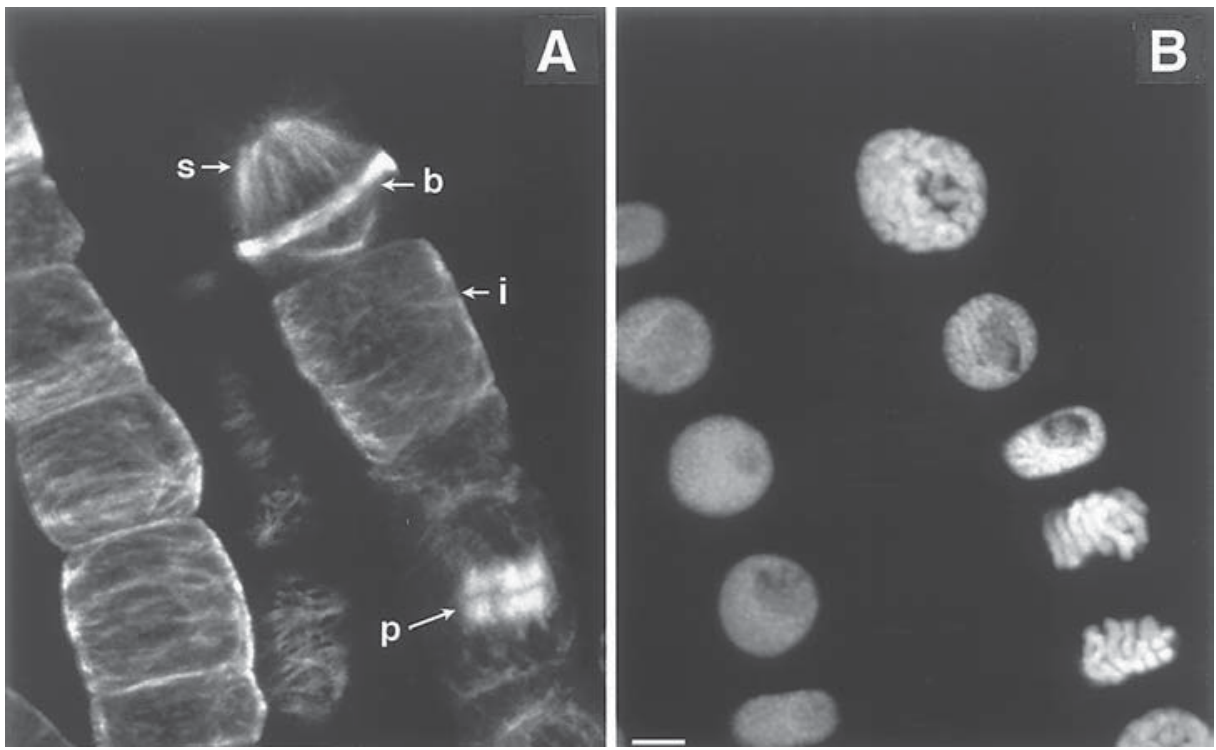

Fig. 7. Microtubule arrays in the meristem of onion (Allium). Eight-day-old Allium root tips were fixed, squashed, and labeled using an anti-tubulin antibody (YOL 1/34, Sera-Labs, Crawley Down, UK). All types of microtubule arrays are illustrated in this field of cells: i, interphase cortical array; b, pre-prophase band; s, mitotic spindle; $p$, phragmoplast. Bar $=20 \mu \mathrm{m}$.

air dried without destroying their 3D structure as can happen with vacuolated cells, such as suspension culture cells. This procedure was originally developed by Wick et al. (19) and has been modified by a number of laboratories. For the best results, use root tips from freshly germinated seedlings that are rapidly growing. This procedure works well with a number of dicot and monocot species (Fig. 7).

1. Excise the root tip from the seedling.

2. Fix roots at room temperature for $45-60 \mathrm{~min}$ in Fixative 3.

3. Remove the fixative and rinse $3 \times$ in PEM 50:1:1 buffer. Roots can be stored for days to weeks at $4^{\circ} \mathrm{C}$ in buffer.

4. Place roots in Enzyme Solution 3 for $10 \mathrm{~min}$.

5. Wash $2 \times$ in PEM 50:1:1 buffer.

6. Place root tips onto subbed slides, put a coverslip on top, and press down hard (squash).

7. Gently remove the coverslips and dry slides at $4^{\circ} \mathrm{C}$ overnight. Alternatively, one can adsorb the cells to poly-L-lysine-coated slides and process the same day. The cells do not have to be dried if poly-L-lysine-coated slides are used.

8. Place slides in a humid box and extract for 10 min with $0.1 \%$ (v/v) Triton $\mathrm{X}-100$ in PEM 50:1:1. 
9. Block any free aldehyde groups with $3 \%(\mathrm{w} / \mathrm{v}) \mathrm{BSA}$ for $15 \mathrm{~min}$ at room temperature.

10. Remove excess blocking buffer and add anti-tubulin antibody [diluted in $3 \%(\mathrm{w} / \mathrm{v})$ BSA] place for $45 \mathrm{~min}$ at room temperature.

11. Rinse primary antibody from the slide using a gentle stream of PBS (pH 7.4) in a wash bottle. Place slides in a beaker of PBS for $15 \mathrm{~min}$.

12. Remove excess PBS from slides and absorb secondary antibody [diluted in $3 \%$ (w/v) BSA] for $45 \mathrm{~min}$. Protect from light.

13. Wash slides as before.

14. Add a few drops of fluorescent mounting medium containing a chromatin binding dye and secure the coverslips in place.

\subsection{Protocol 7: Whole Mount Immunofluorescence in Arabidopsis Roots}

This protocol describes the immunofluorescence localization of proteins in whole-mount Arabidopsis thaliana roots. The combination of whole-mount immunofluorescence and confocal microscopy allows the localization of highly abundant proteins in all root tissues without the need for sectioning. The following protocol is now routinely used to localize the U2B" splicing protein (detected by 4G3 antibody) (Fig. 8).

1. Place three day old seedlings in Fixative 4 for $1 \mathrm{~h}$.

2. Wash the seedlings $3 \times$ for 5 min each in PEM 50:5:5 containing 0.2\% (v/v) NP-40, then resuspend them in PEM 50:5:5 alone.

3. Excise the roots and transfer them to APTES-treated multiwell slides and let them dry down.

4. Digest the roots in Enzyme Solution 4 for $10 \mathrm{~min}$.

5. Wash the roots $6 \times$ in PEM 50/5/5 containing $0.2 \%(\mathrm{v} / \mathrm{v}) \mathrm{NP}-40$ and allow to air dry afterwards.

6. Wash in Blocking Solution for $90 \mathrm{~min}$.

7. Incubate in primary antibody for $2 \mathrm{~h}$ at $37^{\circ} \mathrm{C}$ or overnight at $4{ }^{\circ} \mathrm{C}$ : mouse $4 \mathrm{G} 3$ (Euro-diagnostica B.V., The Netherlands) diluted 1:10 with 3\% (w/v) BSA in PEM 50:5:5.

8. Wash in Blocking Solution for $1 \mathrm{~h}$.

9. Incubate in secondary antibody for $2 \mathrm{~h}$ at $37^{\circ} \mathrm{C}$ : Cy3-conjugated donkey antimouse (Jackson ImmunoResearch Laboratories, West Grove, PA, USA) diluted 1:100 with 3\% (w/v) BSA in PEM 50:5:5.

10. Wash in PEM 50:5:5 containing 0.2\% (v/v) NP-40 for 2 days.

11. Counterstain with DAPI if required and mount in Vectashield.

\subsection{Protocol 8: Whole Mount In Situ Hybridization in Arabidopsis Roots}

The following protocol describes the in situ localization of relatively highly abundant RNAs in whole-mount Arabidopsis roots. It is based on protocols from refs. 20-22, although it has been slightly simplified and adapted for in 


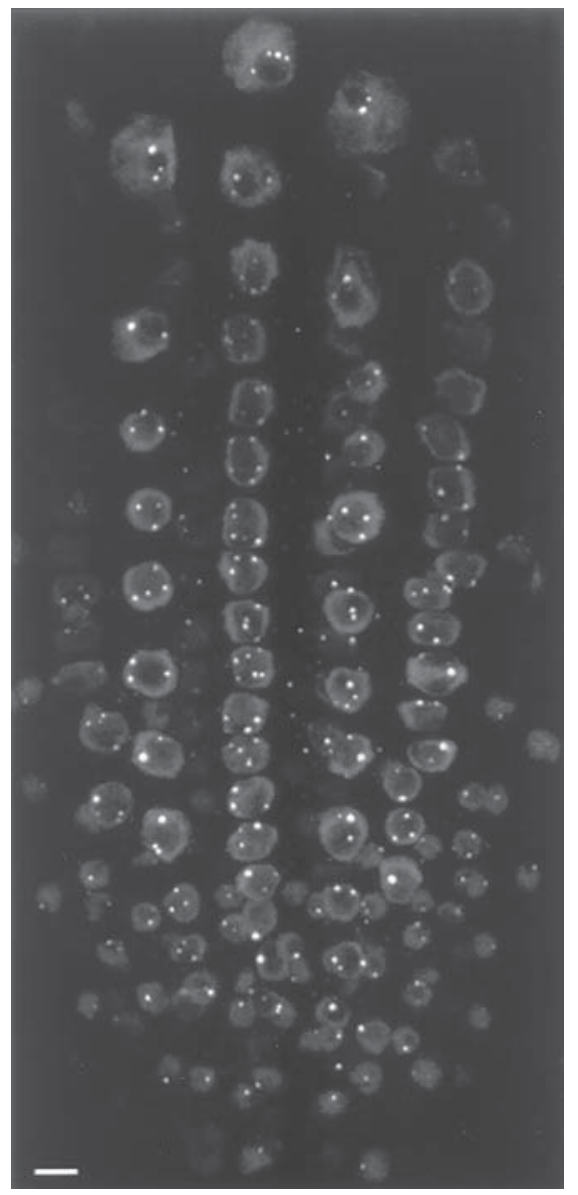

Fig. 8. Whole mount immunofluorescence labeling of an Arabidopsis thaliana root with the 4G3 antibody. The 4G3 antibody labels the snRNP-specific protein U2B". It is interesting to note that the label is confined to the nucleus and is excluded from the nucleolus. The round bright spots, often associated with the nucleolus, are coiled bodies. Bar $=5 \mu \mathrm{m}$.

situ hybridization. For the RNA probe used to develop this procedure, the images obtained appear to be nearly identical to those obtained by immunolocalization (see Fig. 8).

1. Fix 3-day-old seedlings for $1 \mathrm{~h}$ in Fixative 5.

2. Wash $2 \times$ for 3 min each in methanol followed by $4 \times$ for 5 min each in ethanol at $-20^{\circ} \mathrm{C}$.

3. Wash for $30 \mathrm{~min}$ in 1:1 ethanol/xylene.

4. Wash for $3 \mathrm{~min}$ in ethanol followed by a wash for $3 \mathrm{~min}$ in methanol.

5. Wash $2 \times$ for 5 min each in PEM 50:5:5 containing 0.1\% (v/v) Tween, then resuspend in PEM 50:5:5 alone. 
6. Excise the roots and transfer them to APTES-treated multiwell slides and let them dry down.

7. Digest the roots for 10 min in Enzyme Solution 4.

8. Wash the roots $6 \times$ in PEM 50:5:5 containing 0.1\% (v/v) Tween 20 and allow to air dry.

9. Treat with $40 \mu \mathrm{g} / \mathrm{mL}$ of proteinase $\mathrm{K}$ [in PEM 50/5/5 containing $0.1 \%$ (v/v) Tween-20] for $10 \mathrm{~min}$ at $37^{\circ} \mathrm{C}$.

10. Neutralize the proteinase $\mathrm{K}$ by treating for $5 \mathrm{~min}$ with $0.2 \%(\mathrm{w} / \mathrm{v})$ glycine prepared in PEM 50:5:5 containing 0.1\% (v/v) Tween-20.

11. Wash the roots a few times in PEM 50:5:5 and allow them to air dry.

12. Treat the roots $4 \times$ in $1 \mathrm{mg} / \mathrm{mL}$ of $\mathrm{NaBH}_{4}$ in PEM 50:5:5 for 15 min each.

13. Wash the roots in PEM 50:5:5 and give them a final wash in $0.1 \times \mathrm{SSC}$.

14. Add Probe Mixture and incubate at $37^{\circ} \mathrm{C}$ for $24 \mathrm{~h}$.

15. Wash in $0.1 \times \mathrm{SSC}$ for $1 \mathrm{~h}$ at $50^{\circ} \mathrm{C}$.

16. Wash $2 \times$ in PEM 50:5:5 containing 0.1\% (v/v) Tween-20 and allow to dry.

17. Wash in Blocking Solution for $90 \mathrm{~min}$.

18. Incubate in primary antibody for $2 \mathrm{~h}$ at $37^{\circ} \mathrm{C}$ or overnight at $4{ }^{\circ} \mathrm{C}$ : mouse antidigoxin diluted 1:5000 with 3\% (w/v) BSA in PEM 50:5:5.

19. Wash in Blocking Solution for $1 \mathrm{~h}$.

20. Incubate in secondary antibody for $2 \mathrm{~h}$. at $37^{\circ} \mathrm{C}$ : Cy3-conjugated donkey antimouse (Jackson ImmunoResearch Laboratories, West Grove, PA, USA) diluted 1:100 with 3\% (w/v) BSA in PEM 50:5:5.

21. Wash in PEM 50:5:5 containing 0.1\% (v/v) Tween-20 for 2 days.

22. Mount in Vectashield.

\subsection{Protocol 9: Studying Living Cells}

The ability to study living cells has great advantages for understanding active processes. We therefore provide some information for those who would like to pursue such avenues. However, methods of visualizing fluorescent probes in living cells are largely dependent on the cell type and fluorescent probe being used; so no one protocol is preferred. Instead we will discuss the imaging of living cells in terms of being a four-step process and present alternative ways to perform each step. The use of fluorescent probes for studying living cells has also been discussed by Oparka and Read (23).

\subsubsection{Step 1: Immobilization}

If visualization is to be successful, the first step is to immobilize the cell or tissue in a way that keeps the cells alive. The challenge of effective immobilization is to keep cells in the same place for repetitive measurements while maintaining the cells in a healthy state. The most popular way to do this is to embed the sample in agarose. Low-melting-point agarose is often used to minimize the potential for cell damage or induction of heat-shock responses. When using this method for microinjection, a balance must be struck between 
increasing the agarose percentage to keep the cells in place during microinjection while decreasing the percentage for ease of needle movement. This technique has been used successfully for protoplasts $(24)$, pollen tubes $(25,26)$, stamen hairs (27), and root hairs $(7,28)$. Another method of immobilization is the use of adhesive tape. Adhesive tape (a hydrophobic type such as Cellux) is affixed to a microscope slide with its sticky side up by means of double-sided tape. The tissue to be examined is then simply stuck on top. The tissue can be injected "dry" without anything covering it or it can be covered with inert oil such as Voltalef PCTFE Oil (Atochem, Pierre-Bénite, France). The oil prevents drying of the tissue and improves the optical properties of the system. This method is somewhat limited to dry or only slightly moist material; however, with extra precautions, the tissue can be covered with aqueous solutions (29). Staiger et al. (30) and Yuan et al. (31) have used this method for stamen hairs and pea epidermal strips, respectively. A similar approach is to use a water-insoluble, biologically inert adhesive such as dental adhesive or prosthetic adhesive (Secure B401, Factor II, Lakeside, AZ, USA).

\subsubsection{Step 2: Keeping Cells Alive and Healthy}

The easiest way to assess the health of the cells is by carefully examining them with the microscope. The outlines of the organelles should be distinct and it may be possible to see cytoplasmic streaming. When cells become unhealthy, there are often changes in the position and shape of the organelles, particularly the nucleus and cytoplasmic strands, and Brownian motion can sometimes be observed. To keep the cells healthy on the microscope stage they must be kept at an appropriate turgor pressure. For applications utilizing pressure microinjection, turgor may need to be decreased slightly to inject solution from the needle, but care must be taken that this does not induce plasmolysis. Turgor is maintained by keeping the cells covered with buffer or embedded in a gel at an appropriate osmotic strength. The strength of the required osmoticum can be determined by placing cells in buffers containing a range of sorbitol concentrations and using one that does not induce plasmolysis, and that still allows pressure injection. (Plasmolysis is most easily observed in cell corners where the protoplasm retracts from the cell wall.) Even when the cells have been covered with buffer, evaporation can readily occur and will increase the concentration of the bathing solution. In the shortterm (10-15 min), evaporation is usually not a problem, but for long-term experiments $(>20 \mathrm{~min})$ it may be better to keep the specimen in a humid box between measurements or to use some type of perfusion system.

Although maintaining turgor is the most important and most obvious consideration for keeping cells healthy, there are also other considerations includ- 
ing oxygen deprivation, temperature, and light damage. Oxygen deprivation is not a problem for open systems where oxygen can diffuse into the bathing solution and then into the cells, but it can be a problem in a closed chamber. Simple perfusion systems can provide aeration, however. On a large scale, temperature control is rarely a problem on the open microscope stage when room temperature is well controlled. Although some lasers produce a large amount of heat, this is easily compensated for by good ventilation or air conditioning. However, temperature should be a considered when embedding the cells in agarose or other gels. Plant cells can be severely damaged by high-energy laser light and this is due, at least in part, to large local increases in the temperature of laser-irradiated areas. When actively growing pollen tubes are irradiated at the tip with high doses of UV laser light, their growth is retarded and they can burst (Grant Calder, personal communication). The rule of thumb is to use the lowest power that still allows for a clear signal. The important thing to remember is that cell viability is extremely important and that it should be monitored throughout the experiment.

\subsubsection{Step 3: Introduction of Fluorescent Probes}

The main objective of this step is to introduce the probe into as many cells as possible while maintaining their viability. This area has been covered in other reviews $(5,23)$ so we will confine our discussion to the two methods that have been most successful: direct uptake of permeant probes and microinjection. Uptake procedures have the advantages of being able to label many cells simultaneously and that the procedures are straightforward, requiring no special equipment. The experimenter is limited, however, to cell types that can directly take up the probes and to commercially available probes that permeate plant cells. Antibodies and other proteins cannot enter cells this way. Microinjection can deliver antibodies, proteins, and nucleic acids into specific cells. This specificity, however, comes at the cost of reduced sample sizes due to the laborious nature of microinjection. In addition, the apparatus needed for microinjection is costly and microinjection is a skill that requires much practice to attain.

\subsubsection{Direct Uptake of Permeant Probes}

Some probes, due to their lipophilic nature, are readily cell permeant. Procedures for loading such probes into the cell simply require incubating the cells in an appropriate concentration of the dye. Other probes are not cell permeant because of carboxyl groups on the molecules at physiological $\mathrm{pH}$. These molecules can be made membrane permeant by masking their charge with acetoxymethyl groups. This method relies on intracellular esterases to hydrolyze the probe releasing the free dye. There can be problems with this method 
if hydrolysis occurs outside of the cell (32) or if there is incomplete hydrolysis within the cell (33). Protons can also be used to mask the charge of carboxyl groups on dyes. In this case, the cells are incubated in the dye at low $\mathrm{pH}$ (around 4.5) causing the dye to be protonated and membrane permeant. Once the dye is in the cytoplasm $(\mathrm{pH} \mathrm{7)}$, the protons dissociate and the dye becomes trapped within the cell. This method is often referred to as acid-loading. It has been used with some success $(\mathbf{2 8 , 3 4 )}$, but not all cells can survive the $\mathrm{pH}$ stress (35) and there can also be problems with dyes sticking to the cell wall.

\subsubsection{Microinjection of Probes}

There are two types of microinjection: iontophoretic injection and pressure injection. In iontophoretic injection an electrical potential is induced between the bathing solution within the cell and the needle solution by means of a wire immersed in each. A weak current passes through the cell carried by the probe being introduced. Thus, this method requires that the probe be charged and relatively small. This procedure will not work for most proteins. In pressure injection, the microinjection needle is attached to an air supply or syringelike apparatus such that hydraulic pressure is used to force probes into the cell. There are few limitations to the type of probe injected, so probes can range from dyes to proteins to whole virus particles. With pressure microinjection, the volume of the cell is altered (increased) so injection solutions should be kept as small and concentrated as possible. Also, for this reason, the dye-to-protein ratio should be as high as possible while still maintaining probe functionality. In addition, successful injection requires that turgor be exceeded by the injection pressure, so the control of cell turgor is very important (as mentioned previously).

\subsubsection{Example Procedure: Microinjection of Labeled Tubulin}

What follows is an example of one application, pressure microinjection of rhodamine-labeled tubulin into pea stem epidermal cells, which illustrates some of the points discussed previously and provides some specific details (Fig. 9). Pieces of the epidermis are peeled from the stem and placed, epidermal side up, onto tape. The ends of the peels are secured with tape to prevent the peels from lifting off and floating away. Additional pieces of tape are applied parallel to the peels, overlapping the pieces of tape securing the tissue (Fig. 3). In this way a hydrophobic ring is formed around the peels in which buffer can be added to keep the peels wet. This buffer consists of $50 \mathrm{~m} M$ potassium glutamate, $0.5 \mathrm{~m} M$ magnesium chloride, and $2.75 \%$ (w/v) sucrose. Sucrose is added to the buffer to regulate cell turgor. When not on the microscope stage, the slide containing the tissue is kept in a Petri dish with moist paper in order to prevent evaporation. Before starting injections, the tissue is given about $15 \mathrm{~min}$ to recover. Using a water immersion objective lens (Plan-NEOFLUAR 


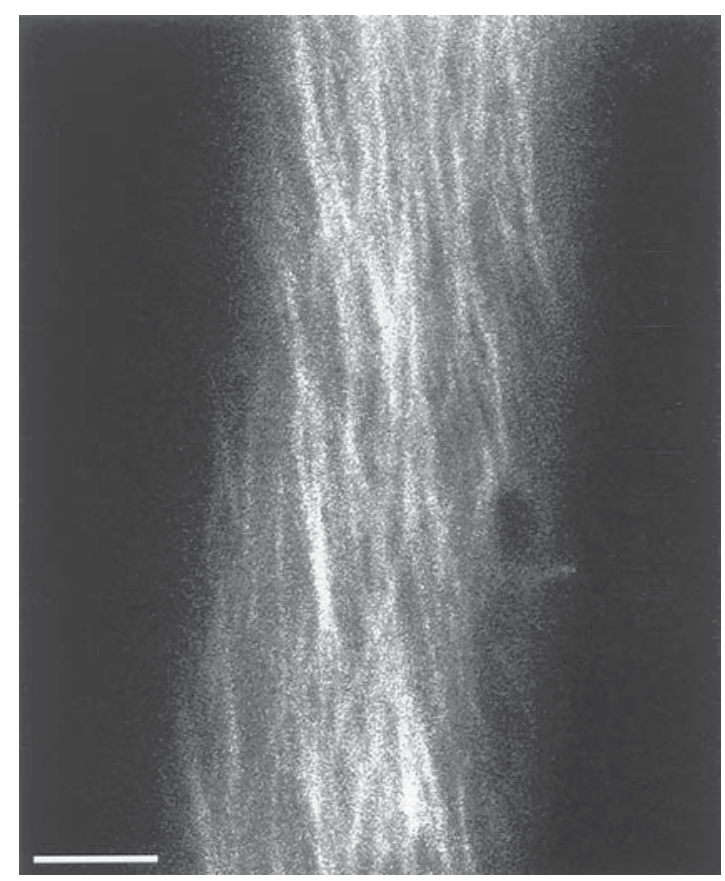

Fig. 9. Microinjection of living pea (Pisum sativum) epidermal cells with rhodamine-tubulin. Projection image of a living pea epidermal cell injected with $1.5 \mathrm{mg} / \mathrm{mL}$ of rhodamine-labeled tubulin. Eight optical sections were taken at $0.3-\mu \mathrm{m}$ intervals. Bar $=5 \mu \mathrm{m}$.

63/1.2), the peel is examined and an area is chosen in which there are many cells that are streaming. We have found that tubulin incorporation is correlated with cytoplasmic streaming. Once an area for injection has been chosen, the water immersion objective lens is replaced with a long working distance objective lens (Nikon Plan 40X/0.35 SLWD).

Tubulin is purified from pig brains and labeled with tetramethyl-rhodamine according to standard procedures [details in (29)]. Because tubulin can selfassemble at room temperature, it is kept on ice. Similarly, the injection needles are kept on ice to reduce the possibility of tubulin assembly in the needle tip. It is generally best to keep purified proteins on ice while injecting them, although chilling of the needles is not usually necessary. The size and shape of the injection needles are very important. The shape is designed to be sharp and the size to be small, but large enough not to become clogged (in this case, approximately $750 \mathrm{~nm}$ outer diameter). One of the most frustrating parts of microinjection of plant cells is the propensity for needles to become clogged by compounds in the cell wall. The injection of viscous solutions such as proteins 
also requires a larger diameter than is needed for injecting aqueous solutions such as dyes. Once the microinjection needles are fitted to their holder, they are tip-filled by placing the needle into a $2-\mu \mathrm{L}$ drop of tubulin in a Petri dish and applying a slight suction to the needle. One advantage of tip-filling is that if the protein goes up the needle easily, it is more likely to be able to come back out of the needle easily. After several hours of injecting, we often observe that it becomes more difficult to get tubulin into the needle. At this point we start using a fresh drop of tubulin because this is an indication that the tubulin is aggregating or becoming assembly incompetent.

Once the needle is filled, it is positioned for injection. The geometry of the cells or tissue should be borne in mind; use a shallow angle of attack that will allow the needle to enter the cytoplasm rather than a steep angle that would enter the vacuole. In the case of the epidermal peel, which is largely flat, the angle of attack is not very important, but for a large cylindrical cell, such as a stamen hair or trichome, it can make a large difference. Similarly, there may be areas within the cell that make better targets for microinjection; e.g., some cells have pockets of cytoplasm at their corners. Once the needle is positioned, it is poked into the cell using movement in the axis of the needle. It is often necessary to apply a small amount of back-pressure to the needle when entering the cell to decrease the chance that turgor will push cytoplasm up the needle. A small amount of tubulin is then injected into the cell. After allowing 1 or 2 min for tubulin assembly, the needle is slowly removed using movement in the axis of the needle. Removal of the needle is the most dangerous part of the injection process. If the needle is removed too quickly, the cell can be damaged and protoplasm leaks out. Pea epidermal cells seem to reseal fairly well such that the needle can be removed within 2 min with little, if any, loss of cytoplasm. Each cell type and tissue has slightly different requirements, but once proficiency is attained with one cell type, others seem easier.

\subsubsection{Step 4: Imaging}

Other chapters in this book deal with the details of different imaging techniques so discussion here is limited. The major consideration with confocal imaging of living cells is avoiding photodamage. Laser intensity should be kept to a minimum as should scan duration. We have been able to follow microtubule reorientation for more than hour while scanning at 3 min intervals by using the fast-photon counting setting and 10\% laser power (from an argon/ krypton laser) on a Bio-Rad MRC-600 confocal microscope. With careful handling, living plant cells can be used very effectively on the confocal microscope.

\section{Notes}

1. A brief treatment with cell wall degrading enzymes is often used to increase antibody penetration into the tissue. The purity and specificity of the enzymes 
will influence the efficiency of this step and the degree of nonspecific tissue damage. Detergents may also be added to extract the tissue.

\section{Acknowledgments}

This work was supported by a Biotechnology and Biological Research Council Linked Research Grant (to R. Warn, P. Shaw, and C. Lloyd), a Biotechnology and Biological Research Council grant in aid to the John Innes Centre, a John Innes Foundation studentship (to K. Boudonck), and an EU Grant (to K. Boudonck).

\section{References}

1. Flanders, D. J., Rawlins, D. J., Shaw, P. J., and Lloyd, C. W. (1989) Computeraided 3-D reconstruction of interphase microtubules in epidermal cells of Datura stramonium reveals principles of array assembly. Development 106, 531-541.

2. Gehring, C. A., Williams, D. A., Cody, S. H., and Parish, R. W. (1990) Phototropism and geotropism in maize coleoptiles are spatially correlated with increases in cytosolic free calcium. Nature $\mathbf{3 4 5}, 528-530$.

3. Oparka, K. J., Prior, D. A. M., and Wright, K. M. (1995) Symplastic communication between primary and developing lateral roots of Arabidopsis thaliana. J. Exp. Bot. 283, 187-197.

4. Carpita, N., Sabularse, D., Montezinos, D., and Delmer, D. (1979) Determination of the pore size of cell walls of living plant cells. Science 205, 1144-1147.

5. Fricker, M., Tester, M., and Gilroy, S. (1994) Fluorescence and luminescence techniques to probe ion activities in living plant cells, in Fluorescent and Luminescent Probes for Biological Activity; A Practical Guide to Technology for Quantitative Real-Time Analysis (W. T. Mason, ed.), Academic Press, London, pp. 360-377.

6. Bush, D. S. and Jones, R. L. (1990) Measuring intracellular $\mathrm{Ca}^{2+}$ levels in plant cells using the fluorescent probes, indo-1 and fura-2. Plant Physiol. 93, 841-845.

7. Clarkson, D. T., Brownlee, C., and Ayling, S. M. (1988) Cytoplasmic calcium measurements in intact higher plant cells: Results from fluorescence ratio imaging of fura-2. J. Cell Sci. 91, 71-80.

8. Yuan, M., Warn, R. M., Shaw, P. J., and Lloyd, C. W. (1995) Dynamic microtubules under the radial and outer tangential walls of microinjected pea epidermal cells observed by computer reconstruction. Plant J. 7, 17-23.

9. Goodbody, K. C. and Lloyd, C. W. (1994) Immunofluorescence techniques for analysis of the cytoskeleton, in Plant Cell Biology: A Practical Approach (N. Harris, and K. J. Oparka, eds.), Oxford University Press, Oxford, pp. 221-243.

10. Nagata, T., Nemoto, Y., and Hasezawa, S. (1992) Tobacco BY-2 cell line as the "HeLa" cell in the cell biology of higher plants. Int. Rev. Cytol. 132, 1-30.

11. Kuss-Wymer, C. L. and Cyr, R. J. (1992) Tobacco protoplasts differentiate into elongate cells without net microtubule depolymerization. Protoplasma 168, 64-72.

12. Gilroy, S., Fricker, M. D., Read, N. D., and Trewavas, A. J. (1991) Role of calcium in signal transduction of Commelina guard cells. Plant Cell 3, 333-344. 
13. Beven, A. F., Lee, R., Razaz, M., Leader, D. J., Brown, J. W. S., and Shaw, P. J. (1996) The organization of ribosomal RNA processing correlates with the distribution of nucleolar snRNAs. J. Cell Sci. 109, 1241-1251.

14. Hozak, P., Hassan, A. B., Jackson, D. A., and Cook, P. R. (1993) Visualization of replication factories attached to a nucleoskeleton. Cell 73, 361-373.

15. Thompson, W. F., Beven, A. F., Wells, B., and Shaw, P. J. (1997) Sites of rDNA transcription are widely dispersed through the nucleolus in Pisum sativum and can comprise single genes. Plant J. 12, 571-581.

16. Wells, B. (1985) Low temperature box and tissue handling device for embedding biological tissue for immunostaining in electron microscopy. Micron Microscop. Acta 16, 49-53.

17. Highett, M. I., Rawlins, D. J., and Shaw, P. J. (1993) Different patterns of rDNA distribution in Pisum sativum nucleoli correlate with different levels of nucleolar activity. J. Cell Sci. 104, 843-852.

18. Shaw, P. J., Highett, M. I., Beven, A. F., and Jordan, E. G. (1995) The nucleolar architecture of polymerase I transcription and processing. EMBO J. 14, 2896-2906.

19. Wick, S. M., Seagull, R. W., Osborn, M., Weber, K., and Gunning, B. E. S. (1981) Immunofluorescence microscopy of organized microtubule arrays in structurally stabilized meristematic plant cells. J. Cell Biol. 89, 685-690.

20. Ludevid, D., Höfte, H., Himelbrau, E., and Chrispeels, M. J. (1992) The expression pattern of the tonoplast intrinsic protein gamma-TIP in Arabidopsis thaliana is correlated with cell enlargement. Plant Physiol. 100, 1633-1639.

21. Bauwens, S., Katsanis, K., Van Montagu, M., Van Oostveldt, P., and Engler, G. (1994) Procedure for whole mount fluorescence in situ hybridization of interphase nuclei on Arabidopsis thaliana. Plant J. 6, 123-131.

22. de Almeida Engler, J., Van Montagu, M., and Engler, G. (1994) Hybridization in situ of whole-mount messenger RNA in plants. Plant Mol. Biol. Rep. 12, $321-331$.

23. Oparka, K. J. and Read, N. D. (1994) The use of fluorescent probes for studies of living plant cells, in Plant Cell Biology: A Practical Approach (N. Harris, and K. J. Oparka, eds.), Oxford University Press, Oxford, pp. 27-50.

24. Gilroy, S. and Jones, R. L. (1994) Perception of gibberellin and abscisic acid at the external face of the plasma membrane of barley (Hordeum vulgare L.) aleurone protoplasts. Plant Physiol. 104, 1185-1192.

25. Miller, D. D., Callaham, D. A., Gross, D. J., and Hepler, P. K. (1992) Free Ca ${ }^{2+}$ gradient in growing pollen tubes of Lilium. J. Cell Sci. 101, 7-12.

26. Pierson, E. S., Miller, D. D., Callaham, D. A., Shipley, A. M., Rivers, B. A., Cresti, M., and Hepler, P. K. (1994) Pollen tube growth is coupled to the extracellular calcium ion flux and the intracellular calcium gradient: effect of BAPTAtype buffers and hypertonic media. Plant Cell 6, 1815-1828.

27. Zhang, D., Wadsworth, P., and Hepler, P. K. (1990) Microtubule dynamics in living dividing plant cells: confocal imaging of microinjected fluorescent brain tubulin. Proc. Natl. Acad. Sci. USA 87, 8820-8824. 
28. Wymer, C. L., Bibikova, T. N., and Gilroy, S. (1997) Cytoplasmic free calcium distributions during the development of root hairs of Arabidopsis thaliana. Plant J. 12, 427-439.

29. Wymer, C. L., Shaw, P. J., Warn, R. M., and Lloyd, C. W. (1997) Microinjection of fluorescent tubulin into plant cells provides a representative picture of the cortical microtubule array. Plant J. 12, 229-234.

30. Staiger, C. J., Yuan, M., Valenta, R., Shaw, P. J., Warn, R. M., and Lloyd, C. W. (1994) Microinjected profilin affects cytoplasmic streaming in plant cells by rapidly depolymerizing actin microfilaments. Curr. Biol. 4, 215-219.

31. Yuan, M., Shaw, P. J., Warn, R. M., and Lloyd, C. W. (1994) Dynamic reorientation of cortical microtubules, from transverse to longitudinal, in living plant cells. Proc. Natl. Acad. Sci. USA 91, 6050-6053.

32. Cork, R. J. (1986) Problems with the application of quin-2-AM to measuring cytoplasmic free calcium in plant cells. Plant Cell Environ. 9, 157-161.

33. Brownlee, C. and Wood, J. W. (1986) A gradient of cytoplasmic free calcium in growing rhizoid cells of Fucus serratus. Nature 320, 624-626.

34. Bush, D. S. and Jones, R. L. (1987) Measurement of cytoplasmic calcium in aleurone protoplasts using indo-1 and fura-2. Cell Calcium 8, 455-472.

35. Elliott, D. C. and Petkoff, H. S. (1990) Measurement of cytoplasmic free calcium in plant protoplasts. Plant Sci. 67, 125-131. 